\title{
'n Kwantitatiewe ondersoek na die invloed van enkele demografiese veranderlikes wat verband hou met vroulike ampsdraers
}

\begin{tabular}{|c|c|}
\hline \multicolumn{2}{|c|}{$\begin{array}{l}\text { Authors: } \\
\text { Petronella Jonck }{ }^{1} \\
\text { Anda le Roux } \\
\text { Lizette Hoffman }^{2}\end{array}$} \\
\hline \multicolumn{2}{|c|}{$\begin{array}{l}\text { Affiliations: } \\
{ }^{1} \text { Department of Psychology, } \\
\text { University of the Free State, } \\
\text { South Africa }\end{array}$} \\
\hline \multicolumn{2}{|c|}{$\begin{array}{l}{ }^{2} \text { Department of Practical } \\
\text { Theology, University of the } \\
\text { Free State, South Africa }\end{array}$} \\
\hline \multicolumn{2}{|c|}{$\begin{array}{l}\text { Correspondence to: } \\
\text { Petronella Jonck }\end{array}$} \\
\hline \multicolumn{2}{|c|}{$\begin{array}{l}\text { Email: } \\
\text { pjonck@cut.ac.za }\end{array}$} \\
\hline \multicolumn{2}{|c|}{$\begin{array}{l}\text { Postal address: } \\
\text { PO Box } 32378, \text { Fichardtpark, } \\
\text { Bloemfontein } 9317\end{array}$} \\
\hline \multicolumn{2}{|c|}{$\begin{array}{l}\text { Dates: } \\
\text { Received: } 13 \text { Feb. } 2012 \\
\text { Accepted: } 16 \text { July } 2012 \\
\text { Published: } 09 \text { July } 2013\end{array}$} \\
\hline \multicolumn{2}{|c|}{$\begin{array}{l}\text { How to cite this article: } \\
\text { Jonck, P., Le Roux, A. \& } \\
\text { Hoffman, L., 2013, "n } \\
\text { Kwantitatiewe ondersoek } \\
\text { na die invloed van enkele } \\
\text { demografiese veranderlikes } \\
\text { wat verband hou met } \\
\text { vroulike ampsdraers', In die } \\
\text { Skriflig/In Luce Verbi 47(1), } \\
\text { Art. \#102, } 8 \text { pages. http:// } \\
\text { dx.doi.org/10.4102/ids. } \\
\text { v47i1.102 }\end{array}$} \\
\hline \multicolumn{2}{|c|}{$\begin{array}{l}\text { Copyright: } \\
\text { (C) 2013. The Authors } \\
\text { Licensee: AOSIS } \\
\text { OpenJournals. This w } \\
\text { is licensed under the } \\
\text { Creative Commons } \\
\text { Attribution License. }\end{array}$} \\
\hline \multicolumn{2}{|l|}{ Read online: } \\
\hline 回保回 & $\begin{array}{l}\text { Scan this QR } \\
\text { code with your } \\
\text { smart phone or } \\
\text { mobile device } \\
\text { to read online. }\end{array}$ \\
\hline
\end{tabular}

Hierdie artikel ondersoek lidmate se houding teenoor vroulike ampsdraers. Vir die doel van hierdie navorsingsprojek is die volgende navorsingsvraag geformuleer: Wat is kerklidmate se houding teenoor vroue as ampsdraers in die gemeente? Hierdie navorsingsvraag is met behulp van die volgende hipotese ondersoek: Daar is statisties-beduidende verskille tussen kerklidmate se houding teenoor vroulike ampsdraers en 'n aantal demografiese veranderlikes soos die geografiese ligging, die geslag, die huwelikstatus en die ouderdom. 'n Totaal van 1052 respondente bestaande uit 326 (31\%) lidmate van die Nederduitse Gereformeerde Kerkfamilie, 311 (29\%) lidmate van die Christelike Herlewingskerk, 217 (21\%) lidmate van die Gereformeerde Kerk en 198 (19\%) lidmate van die Rooms-Katolieke Kerk is by die ondersoek betrek. Data is met behulp van 'n biografiese vraelys, asook die Petro Jonck Houding teenoor Vroulike Ampsdraers-vraelys ingesamel. Meerveranderlike variansie-ontledings is toegepas. Satistiese analise het getoon dat kerklidmate deurgaans 'n positiewe houding aangaande vroulike ampsdraers aanneem. Verder is gevind dat die geslag, die huwelikstatus en die geografiese ligging die grootste invloed op kerklidmate se houding ten opsigte van vroulike ampsdraers uitgeoefen het. Die opleidingsvlak het geen statisties-beduidende invloed op lidmate se houding teenoor vroulike ampsdraers uitgeoefen nie.

A quantitative investigation of the influence of some demographic variables as it pertains to clergywomen. This article investigates the attitude of church members towards clergywomen. For the purpose of this research project, the following research question has been formulated: What is church members' attitude towards clergywomen in the congregation? This research question was explored by means of the following hypothesis: There are statistically significant differences between church members' attitude towards clergywomen and a number of demographic variables such as geographic location, gender, marital status and age. A total of 1052 respondents that included 326 (31\%) members of the Dutch Reformed Church family, 311 (29\%) members of the Christian Revival Church, 217 (21\%) members of the Reformed Church and 198 (19\%) members of the Roman Catholic Church were involved. Data were gathered by means of a biographic questionnaire and the Petro Jonck Attitude towards Female Officebearers Questionnaire. Multivariate analysis of variance was applied. A statistical analysis indicated that church members assume a positive attitude with regard to female office-bearers. Furthermore, it was concluded that gender, marital status and geographic location exerted the greatest influence on the dependent variable (attitude towards clergywomen) while, academic qualification had no statistically significant influence.

\section{Inleiding}

Die kerk as instelling ervaar tans ingewikkelde problematiek ten opsigte van haar interne en ekstrene verhoudings. Dit manifesteer onder andere in die finansiële druk waaronder verskeie kerke gebuk gaan, asook in geslagsongelykheid. Tans is laasgenoemde verskynsel 'n belangrike en aktuele fokuspunt in kerklike verband. Die Nasionale Sinode van die Gereformeerde Kerke in Suid-Afrika kon nie in 2012 tot 'n beslissing kom rakende die rol van vroue in die gemeente nie, en dit te midde van die aanhoor van verskeie beswaarskrifte (Smit 2012:9).

Suid-Afrika se demokratiese regering het doelbewus omvattende beleidsraamwerke neergelê om geslagsongelykheid te elimineer. In 1993 het Suid-Afrika die konvensie oor die uitwissing van alle vorms van diskriminasie teen vroue onderteken. Daarin word onderneem om wetgewing daar te stel wat diskriminasie verbied en om toe te sien dat vroue gelyke toegang tot indiensneming het (De Beer 2007:111). Ten spyte hiervan bedreig die hardnekkige voortbestaan van geslagstereotipering, ingebed in die kultuur en godsdienstige dogma, steeds vroue se grondwetlike regte. 
Stereotipering behels onder andere die aangeleerde predisposisie dat lede van 'n bepaalde groep, dikwels die buitegroepe, oor afkeuringswaardige karaktereienskappe beskik (Obst et al. 2011:427). Hierdie stereotipering is deel van die kognitiewe aspek van 'n negatiewe houding (Jonck, Le Roux \& Verster 2007:50). Derhalwe is dit noodsaaklik om die konsep, houding, te ondersoek ten einde ongeoorloofde diskriminasie te identifiseer en te hanteer.

\section{Literatuuroorsig}

Houdings en wilshandelinge wat te kenne gee dat een geslag inherent meerderwaardig en die ander inherent minderwaardig is, word in kerklike kringe geregverdig deur Skrifgegewens aan te haal oor die plek van vroue in die gemeente-opset. Aandag word dus aan die term, houding, geskenk waarna vermelde Skrifgegewens onder die loep kom.

\section{Houdings}

Tervo, Palmer en Redinius (2004:908) definieer houding as 'n geneigdheid om ' $n$ entiteit met ' $n$ mate van goedkeuring of afkeur te evalueer. Evalueringsresponse, aldus Kleynhans en Kotzé (2010:408), behels kognitiewe, affektiewe en konatiewe komponente. Die kognitiewe dimensie behels intellektuele beredenering en dus die oortuiging dat die houdingsobjek oor bepaalde karaktereienskappe beskik. Gedrag wat verband hou met die houdingsobjek sal derhalwe tot spesifieke uitkomste lei (Jonck et al. 2007:48). Die affektiewe dimensie van 'n houding bestaan uit die individu se emosies teenoor die stimulus, veral positiewe en negatiewe evaluerings (De Houwer 2011:466).

Die neiging om 'n spesifieke handeling wat tot nadeel van die houdingsobjek of teikengroep strek, uit te voer, word op sy beurt as diskriminasie gedefinieer (Jasinskaja-Lahti et al. 2009:107). Diskriminasie kan derhalwe beskou word as die konatiewe dimensie van 'n ongunstige houding (Cheung, Noel \& Hardin 2011:256).

\section{Diskriminasie}

Geslagsdiskriminasie het betrekking op die sosiaalgekonstrueerde verskille tussen mans en vroue, asook die daaropvolgende ongelyke magsverhouding (StewartThomas 2010:407). Navorsing deur Piper en Grudem (2006:469) dui aan dat ten spyte van 'n positiewe houding teenoor vroulike leraars, 'n onderliggende, dog subtiele teenkanting teenoor voorgenome vroulike ampsdraers voorkom. 'n Studie deur Lummis en Nesbitt (2000), met spesifieke verwysing na vroulike predikante, bevind dat passiewe diskriminasie aan die orde van die dag is. Dit kom voor waar belangrike inligting weerhou word, of waar vroue in poste aangestel word wanneer hulle nie langer as 'n bedreiging vir die man beskou word nie, of waar die kanse op mislukking buitengewoon groot is. Hamman (2010:769) maak melding daarvan dat slegs enkele vroue na afloop van hulle teologiese studie beroep word. Diegene wat wel beroep word, word in tydelike of deeltydse poste aangestel teen swak betaling en min vooruitsigte.
Die aangeleerde predisposisie dat lede van 'n bepaalde groep oor afkeurenswaardige karaktereienskappe beskik, dui op stereotipering en impliseer die kognitiewe dimensie van 'n negatiewe houding (Obst et al. 2011:427).

\section{Stereotipering}

Stereotipering impliseer 'n kognitiewe proses waar spesifieke gedragseienskappe toegeken word aan individue, gebaseer op hulle lidmaatskap aan 'n bepaalde groep - dit kan ook betrekking hê op 'n enkele individu (StewartThomas 2010:408). Die grondslag van alle stereotipering behels die differensiële persepsie van groepe. In 'n poging om die wêreld te organiseer en te klassifiseer en daardeur 'n groot verskeidenheid prikkels te kontroleer, plaas individue ander en hulself in bepaalde groepe. Karaktereienskappe word aan die verskillende groepe toegeken sonder inagneming van individuele verskille (Todd, Galinsky \& Bodenhausen 2012:95).

Die affektiewe dimensie van 'n houding korreleer met antipatie, of die onberedeneerde hewige gevoel van afkeer wat lede van die binnegroep teenoor lede van die buitegroep koester as gevolg van stereotipering. Die affektiewe dimensie van 'n ongunstige houding word in vooroordeel gereflekteer (Jonck et al. 2007:50).

\section{Vooroordeel}

Vooroordeel verwys na houdingsgebaseerde partydigheid. Dit beteken om iemand vooraf, na aanleiding van 'n bepaalde kenmerk, te oordeel (Du Plooy-Cilliers \& Louw 2003:52). Vooroordeel is 'n destruktiewe aspek van sosiale gedrag en gee dikwels aanleiding tot verontregting, gebaseer op ras, geslag en seksuele oriëntasie (Taylor, Peplau \& Sears 2003:168).

Stereotipering, vooroordeel en diskriminasie is onderling verbandhoudende elemente van groepantagonisme (Taylor et al. 2003:170) wat prinsipieël op die konstruk van sosiale identiteit gebaseer word. Ten einde 'n positiewe groepsidentiteit te handhaaf, beskou groepslede karaktereienskappe wat verbandhoudend tot die groep is as verhewe bo dié van die buitegroep. Die binnegroep openbaar derhalwe houdingsgebaseerde partydigheid en groepslede veroorloof hulself gedrag wat tot nadeel van die buitegroep strek, ten einde die binnegroep van die buitegroep te differensieer (Obst et al. 2011:427).

Groepantagonisme op grond van geslag het diepliggende steun in 'n ideologiese stelsel waar mans meer mag en voorregte geniet as vroue. Hierdie ideologiese denkrigting word patriargie genoem. Dit was in die verlede 'n integrale deel van kerklike dogma (Van Helden 2002:768-769), ingevolge waarvan mans godsdienstige dogma koöpteer om hulle magsposisies in patriargale gemeenskappe te regverdig en te behou (Ebere 2011:480).

Voorts word aandag geskenk aan openbaringshistoriese Skrifgegewens oor die plek en rol van vroue in die gemeente. 
Met inagneming dat hierdie studie 'n sosiaal-psigologiese perspektief bied, word slegs kortliks op enkele Skrifgegewens gelet.

\section{Skrifgegewens oor vroue as ampsdraers in die gemeente}

Die Skrifgedeeltes wat verband hou met die plek van vroue in die gemeente-opset, kan in drie tydsgrepe verdeel word.

\section{Vroue se plek in die Ou Testament}

Aangesien die geloofsgemeenskap in die Ou Testament 'n ander gestalte het as dié van die geloofsgemeenskap in die Nuwe Testament, is die gegewens rakende die plek van vroue in die Ou-Testamentiese geloofsgemeenskap nie sonder meer direk van toepassing op die plek van vroue in die Nuwe-Testamentiese geloofsgemeenskap nie. Ampte ${ }^{1}$ in die $\mathrm{Ou}$ Testament het die amp van priester en profeet ingesluit (vgl. Kloppers 1988:14). In Deuteronomium 10:8 word gemeld:

In dié tyd het die Here die stam van Levi afgesonder om die verbondsark van die Here te dra, om voor die aangesig van die Here in sy diens te staan en in sy Naam te seën tot vandag toe.

Die amp van priester was dus die enigste amp wat direk in verband met tempeldiens gestaan het (Rees 2003:33). In die $\mathrm{Ou}$ Testament word nie verwysings na vroulike priesters gevind nie. Daar is wel vermeldings van vroulike profete, voorbeeld in 2 Konings 22:14 en verdere. Hier word verwys na die profetes Gulda, vrou van Sallum, die klerebewaarder. Sy is deur priesters genader om God se wil aan hulle bekend te maak. Hoewel mans oor die algemeen in die ampte opgetree het, het die Here soms 'n vrou geroep vir sulke besondere take (vgl. Kloppers 1988:15).

\section{Vroue se plek tydens Jesus se lewe op aarde}

Die plek en taak van gelowige vroue tydens Jesus se lewe op aarde word op verskillende wyses in die evangeliebeskrywings uitgebeeld. Volgens Dreyer (2006:1679) word vroue in die Evangelie van Markus oorwegend in 'n positiewe lig gesien, terwyl vroue in die Matteusgemeenskap nie as gelyke deelnemers gesien is nie. Hoewel Lukas poog om vroue te betrek, is hy tog subjektief oor vroue (Dreyer 2006:1698). Dreyer daag mense uit om die sinoptiese Evangelies noukeurig en krities te lees ten einde weg te beweeg van 'n 'dualistiese model van bevoordeelde manlike dominansie en vroulike ondersteuning' na 'n model wat nuwe kriteria insluit (Dreyer 2006:1699).

Vervolgens word na 'n paar aspekte van vroue in die Evangelies verwys (vgl. Hurley 1981:82-83; Sparrow 2006:14-16):

- Vroue se geloofslewe word op dieselfde vlak as dié van mans gereken. In Lukas 10:38-42 het Maria aan die voete van Jesus gesit en na sy woord geluister soos die mans gedoen het. Volgens Johannes 4:27 het die dissipels hulle verwonder dat Jesus op dieselfde wyse met 'n vrou in

1.Volgens Prinsloo (1988:24) is dit te simplisites om van amp in die Ou Testament te praat. Daarom word in hierdie afdeling na $a m p$ verwys om die kompleksiteit van die saak te erken. gesprek was as wat Hy gereeld met mans was. Ingevolge Lukas 13:10-17 was Jesus in die sinagoges waar daar mans en vroue was, besig om te leer toe hy die vrou genees het.

- Vroue was ongehinderd deel van die kring volgelinge van die Here. Matteus 27:55 dui aan dat daar baie vroue was wat Jesus gevolg en gedien het. Ook word in Markus 15:41 aangetoon dat daar baie vroue was wat Hom gevolg het en wat saam met Hom na Jerusalem gegaan het. Lukas 23:49 vermeld dat vroue Jesus se volgelinge en getuies was.

- Vroue het ' $n$ besondere rol in die fisiese versorging en bediening van die Here en sy dissipels gespeel. In Johannes 12:1-11 het Martha vir Jesus 'n maaltyd voorberei en Hom bedien, terwyl Maria die voete van Jesus gesalf en afgedroog het. In Johannes 20:16-18 verskyn Jesus aan Maria na sy opstanding en sy word die eerste verkondiger van Jesus se opstanding.

\section{Vroue se plek in die apostoliese tyd}

Die meeste inligting oor die plek en taak van vroue in die Vroeë Kerk word in Handelinge en die sendbriewe gevind. Dit lei tot die volgende gevolgtrekkings (vgl. Deddens 1988:345-347; Rees 2003:66):

- Vroue was sonder beperking deel van die gemeentes. In Handelinge 1 bid verskeie vroue, waaronder die moeder van Jesus, saam met die dissipels toe hulle gewag het op die uitstorting van die Heilige Gees. Vroue het op verskillende wyses hulle gawes in die gemeente en tot opbou van die gemeente beoefen. Die vroeë gemeentes het dikwels in vooraanstaande vroue se huise bymekaar gekom. In 1 Korintiërs 11:5² word ook melding gemaak van vroue wat bid en profeteer.

- Vroue was op 'n besondere wyse by die versorging van die apostels en by die barmhartigheidswerk in die gemeente betrokke. (Vgl. 1 Tim 5:10 en Hand 9:36-43.)

- Paulus verwys ook na verskeie vroulike medewerksters in sy briewe, byvoorbeeld Priscilla (Rom 16:3), Febe (Rom 16:1), Euodia en Sintige (Fil 4:3) wat almal klaarblyklik verskillende rolle in hulle gemeentes vervul het.

In hierdie afdeling is baie kursories aandag geskenk aan die rol van vroue tydens drie tydsgrepe. Vervolgens word aandag aan demografiese veranderlikes geskenk wat moontlik ' $n$ invloed op lidmate se houding teenoor vroulike ampsdraers kan uitoefen.

\section{Demografiese veranderlikes}

Volgens Du Plooy en Grobler (2002:11) kan demografiese veranderlikes onder andere verdeel word in persoonlike, sosio-kulturele en sosio-ekonomiese veranderlikes. Vir die doel van hierdie navorsingsartikel word aandag aan die persoonlike veranderlikes van die respondente geskenk. Die persoonlike veranderlikes waarop gefokus word, is die geografiese ligging, die geslag, die huwelikstatus en die ouderdom van respondente.

2.Vergelyk ook Cohick (2006:81-97) se bespreking van die implikasie van hierdie Skrifgedeelte vir vroue in die amp. 


\section{Geografiese ligging}

Die geografiese ligging sluit sowel die streek waar die proefpersoon woonagtig is, as die verskil tussen stedelike en plattelandse gebiede in. Verskeie navorsingstudies fokus op die belangrikheid van sosiale netwerke en die geografiese ligging vir die vorming van individuele houdings, gedrag en besluitnemingsprosesse (Gore \& Hollywood 2009:1008). Dienooreenkomstig veronderstel Leavitt-Alcántara (1999:1) dat daar 'n noue verband is tussen godsdiens en die geografiese ligging. Hoewel geen studie uit die literatuur geidentifiseer kon word wat ondersoek ingestel het na die invloed van die geografiese ligging op lidmate se houding teenoor vroulike ampsdraers nie, is daar nietemin ondersoek ingestel na 'n moontlike verband.

\section{Geslag}

'n Studie deur Rees (2003:113-116) bevind dat die meeste respondente 'n lae positiewe en selfs negatiewe houding handhaaf ten opsigte van vroue in die amp van leraar. Hiermee saam voel $50 \%$ vroue in leierskapsposisies in die kerkgemeenskap dat vroue hulself ondergeskik moet stel aan manlike dominansie. Vroulike lidmate ondersteun hierdie tendens en $63 \%$ van die genoemde responsgroep voel dat vroue hulself aan manlike dominansie moet onderwerp. Resultate in dieselfde studie toon dat $90 \%$ van die manlike respondente van mening is dat vroue nie genoeg geleenthede gebied word om hulle godgegewe gawes aan te wend nie. Slegs $60 \%$ van die vroulike respondente het 'n soortgelyke mening gerapporteer (Rees 2003:113-116). Rees se SuidAfrikaanse studie sluit respondente in van die Church of the Province in South Africa, Church of England in South Africa en die Baptist Union.

\section{Huwelikstatus}

Geen studie kon geïdentifiseer word rakende die invloed van huwelikstatus op lidmate se houding teenoor vroulike ampsdraers nie. Tog is ondersoek hieroor ingestel. Die motivering hiervoor is dat individue neig om hulle houdings aan te pas in ooreenstemming met die van hulle lewensmaat om daardeur hulle huweliksverhouding te versterk of te onderhou (Cheung et al. 2011:256). Getroude vroue mag dalk die houding van hulle eggenote internaliseer ten einde die huweliksbande te versterk.

\section{Ouderdom}

Navorsing dui daarop dat die sosialiserende invloed wat individue ervaar wanneer hulle jonk is 'n besliste invloed uitoefen op die wyse waarop hulle verder deur hulle lewens dink (Potgieter 1994:59). Indien 'n individu gesosialiseer is in ' $n$ era waar vroue nie oor sekere regte beskik het nie, sal hierdie sosialisering ' $n$ invloed op die persoon se denke rondom vroueregte uitoefen. Hendriks (2003:10) toon aan dat die situasie in veral die Nederduitse Gereformeerde Kerk tans betreurenswaardig is as gevolg van die onvermoë van ouer lidmate om by veranderings aan te pas.

\section{Navorsingsmetode}

Die navorsingshipotese vir die artikel word soos volg geformuleer: Daar is statisties-beduidende verskille tussen kerklidmate se houding teenoor vroulike ampsdraers en 'n aantal demografiese veranderlikes, insluitende geografiese ligging, geslag, huwelikstatus en ouderdom. Voorts word die volgende hipoteses gemaak:

- Stedelinge sal 'n positiewer houding teenoor vroulike ampsdraers toon.

- Vroulike lidmate sal die neiging toon om 'n positiewer houding teenoor vroulike ampsdraers te huldig.

- Ongetroude lidmate sal 'n positiewer houding teenoor vroulike ampsdraers openbaar.

- Jonger lidmate sal 'n positiewer houding teenoor vroulike ampsdraers rapporteer.

\section{Navorsingsontwerp}

Die navorsingsontwerp in hierdie studie is nie-eksperimenteel en beskrywend van aard. Die doel van 'n beskrywende metode is om die huidige stand van sake te belig. Gevolglik word slegs op die hoofeffekte gefokus en nie op interaksies tussen veranderlikes nie (Salkind 2012:197). Hierdie ontwerp heet ex post facto-navorsing, aangesien die proefpersone reeds voor die aanvang van die studie aan hulle onderskeie groepe behoort het. ' $n$ Kruis-seksionele ontwerp is toegepas, wat ideaal is vir die beskrywende funksie wat met ex post facto-navorsing geassosieer word. Die breë tyd-ruimtelike omstandighede, ingevolge die kruis-seksionele ontwerp waarbinne die navorsing plaasvind, behels dat 'n steekproef van die gekose teikengroepe op 'n spesifieke tydstip gedoen is, naamlik tydens oggenderedienste (Leedy \& Ormrod 2010:228).

\section{Die ondersoekgroep}

'n Lys van gemeentes is van die verskillende denominasies verkry, waarna individuele gemeentes gekontak is met 'n uitnodiging om aan die studie deel te neem. Die bereidwillige individuele gemeentes in dorpe en stede is vervolgens vanaf hulle amptelike telefoonlys gekontak. Die teikengroep het uiteindelik uit kerklidmate bestaan wat afkomstig was van 36 individuele gemeentes uit vier kerkdenominasies. Die vraelyste is by die deure na afloop van die oggenderediens uitgedeel. Kerklidmate kon die vraelys tuis voltooi en die daaropvolgende Sondag tydens die oggenderedienste terugbesorg of by die kerkkantoor aflewer. Kerklidmate is volgens 'n beskikbaarheidsteekproef geselekteer.

Deelname aan die ondersoek het vrywillig en anoniem plaasgevind. Alle vraelyste is as vertroulike beskou. Die kerklidmate is tydens die betrokke oggenderedienste deur die leraar ingelig oor die inhoud, uitkomste en doel van die navorsing, en dat bevindings na verwerking beskikbaar gestel sou word.

Die teikengroep sluit kerklidmate in van die RoomsKatolieke Kerk, die Nederduitse Gereformeerde Kerkfamilie, die Gereformeerde Kerke in Suid-Afrika (GKSA), asook 
die Christelike Herlewingskerk. Die steekproef bestaan uit 1052 kerklidmate afkomstig uit al nege provinsies in SuidAfrika. Die totaal van 1052 vraelyste verteenwoordig 326 (31\%) van die Nederduitse Gereformeerde Kerkfamilie, 311 (29\%) van die Christelike Herlewingskerk, 217 (21\%) van die Gereformeerde Kerke van Suid-Afrika (GKSA), asook 198 (19\%) van die Rooms-Katolieke Kerk.

\section{Meetinstrument}

Ten einde die empiriese doelwitte te verwesentlik, is van 'n gestruktureerde vraelys gebruik gemaak wat na afloop van vier afsonderlike loodsstudies ontwikkel is. Die loodsstudies het telkens uit 50 respondente afkomstig van die Nederduitse Gereformeerde Kerk en die Christelike Herlewings Kerk bestaan. Tydens die finale loodsstudie is die gesamentlike alfakoëffisiënt van al drie houdingskale op 0.831 bereken. Die vraelys kom vervolgens onder die loep.

\section{Biografiese vraelys}

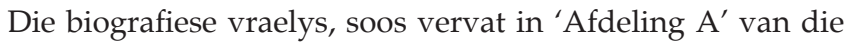
vraelys, bevat die volgende inligting wat deur elke respondent voltooi moes word: geslag, huwelikstatus, ouderdom, hoogste akademiese kwalifikasie, maandelikse inkomste, gemeentlike betrokkenheid, huistaal, bevolkingsgroep, denominasie, asook godsdienstige oriëntasie. Vir die doeleindes van hierdie artikel is slegs die geografiese ligging, geslag, ouderdom en huwelikstatus statisties verwerk.

\section{Kwantitatiewe vraelys}

'n Likert-tipe vraelys is aangewend om die verlangde data in te samel. Aangesien daar tans nie ' $n$ meetinstrument is wat die lidmate se houding teenoor vroulike ampsdaers meet nie, is 'n vraelys deur die navorser saamgestel. Dit bestaan uit die volgende drie afdelings: 'Afdeling $\mathrm{B}$ ' handel oor algemene vrae en bevat tien stellings om die respondente se houding teenoor vroue wat gesagsposisies beklee, te ondersoek. 'Afdeling C' bestaande uit tien vrae waardeur die respondente se houding met betrekking tot vroue as ampsdraers in die gemeente gemeet word, met spesifieke verwysing na die prediking. In 'Afdeling D' word die respons wat die houding by die respondente ontlok, gemeet ten einde te bepaal of die houding ooreenstem met reeds bestaande houdings. Hierdie afdeling is op die kognitief-affektief-konatiewe model gebaseer en behels tien items ooreenkomstig die kognitiewe dissonansieteorie.

Vir elke item in bogenoemde afdelings moes die respondente op ' $n$ vierpuntskaal aantoon in watter mate hulle die stelling saamstem of verskil. Waardes van vier ('stem in 'n baie groot mate saam') tot een ('stem geensins saam nie') is aan elke responskategorie toegeken. Die maksimumtelling wat vir elke afdeling behaal kon word, was 40 . Die minimumtelling was 10, met' $n$ teoretiese gemiddeld van 25 . Waardes bokant 25 dui op 'n positiewe houding en waardes laer as 25 op 'n negatiewe houding. Vir die totale skaal is die maksimumtelling wat behaal kon word 120. Die minimumtelling was 30 , met ' $n$ teoretiese gemiddeld van 75 .

\section{Psigometriese eienskappe}

Ten einde die betroubaarheid van die houdingskale vas te stel, is Cronbach se alfakoëffisiënt toegepas. Die interne metingskonsekwentheid van die houdingskale, oftewel Cronbach se alfakoëffisiënt, is hoogs betroubaar, met 'n gesamentlike koëffisiënt van 0.86 . Om konstrukgeldigheid te toets, is ' $n$ twee-faktor-ontleding gedoen. Dit het getoon dat 24 van die 30 items oor goeie konvergente en divergente geldigheid beskik.

\section{Statisiese ontleding}

Meerveranderlike variansie-ontleding is aangewend om die interaktiewe en onafhanklike uitwerking van twee of meer onafhanklike veranderlikes op 'n aantal afhanklike veranderlikes te meet. Die onafhanklike veranderlikes in hierdie ondersoek was die geografiese ligging, die geslag, die huwelikstatus en die ouderdom, terwyl die afhanklike veranderlikes die houding teenoor vroulike ampsdraers verteenwoordig soos dit deur die drie subskale gemeet is. Waar p-waardes aanduidend is van statistiese beduidendheid, is Cohen se d-toets toegepas om die praktiese beduidendheid aan te toon.

Indien die $F$-waarde van die meerveranderlike variansieontleding beduidend is, kon enigeen van die post hocprosedures aangewend word om die bepaalde vergelykings, wat wel beduidend van nul verskil, op te spoor. Daar is verskeie sodanige prosedures beskikbaar, waarvan dié van Scheffé gebruik is asook die $T$-toets vir onafhanklike groepe wat slegs oor twee vlakke beskik.

\section{Resultate}

In Tabelle 1 tot 5 word die datagegewens aangaande die demografiese veranderlikes aangetoon in terme van die frekwensie, die presentasies en die gemiddeldes.

Volgens Tabel 1 was die gemiddelde telling vir die gesamentlike groep hoër as die teoretiese gemiddeld $(\overline{\mathrm{X}}=86.44 ; s=10.23)$. Dit dui daarop dat hierdie groep as geheel 'n positiewe houding teenoor vroulike ampsdraers in die kerk huldig. Diegene wat in stedelike gebiede woonagtig was $(N=473 ; \overline{\mathrm{X}}=86.44 ; s=10.23)$, het 'n hoër gemiddelde telling behaal as die plattelandse respondente $(N=575 ; \overline{\mathrm{X}}=85.81$; $s=10.77)$.

Wanneer daar na die streeksverspreiding van die respondente se frekwensies gekyk word, blyk dit dat die meerderheid respondente van die Vrystaat afkomstig was $(N=179)$. Die oorblywende respondente was redelik eweredig in die oorblywende streke versprei. Die gesamentlike groep se gemiddelde telling was weereens hoër as die teoretiese gemiddeld ( $\overline{\mathrm{X}}=86.09 ; s=10.77$ ), wat daarop dui dat hierdie groep as geheel positief teenoor vroulike ampsdraers was. Die Vrystaat het die hoogste gemiddelde telling getoon $(\overline{\mathrm{X}}=88.56 ; s=9.38)$, terwyl die Wes-Kaap die laagste gemiddelde telling behaal het $(\overline{\mathrm{X}}=83.61 ; s=8.67)$. Sien Tabel 2. 
Volgens Tabel 3 was die oorgrote meerderheid van die respondente ongetroud. Die gesamentlike gemiddelde telling was $86.12(s=10.83)$, terwyl die teoretiese gemiddeld 75 was. Hierdie groep was dus positief teenoor vroulike ampsdraers ingesteld. Die ongetroude respondente het die hoogste gemiddelde telling behaal $(\overline{\mathrm{X}}=86.45 ; s=10.69)$.

Volgens Tabel 4 het 639 vroulike respondente en 413 manlike respondente aan die ondersoek deelgeneem. Hierdie groep as geheel se gemiddelde telling was $86.11(\bar{X}=10.82)$, terwyl die teoretiese gemiddeld 75 was. Die groep as geheel was dus positief teenoor vroulike ampsdraers gesind. Die vroulike respondente se gemiddelde telling $(\overline{\mathrm{X}}=87.81 ; s=9.50)$ was heelwat hoër as dié van die manlike respondente $(\overline{\mathrm{X}}=83.49$; $s=12.15)$.

Die respondente is in vier ouderdomskategorieë ingedeel, naamlik jonger as 19 jaar, 20-39 jaar, 40-59 jaar en 60 jaar en ouer. Hierdie groep se gesamentlike gemiddelde telling was hoër as die teoretiese gemiddeld ( $\bar{X}=86.11$; $s=10.83$ ), wat weereens op 'n positiewe houding dui. Die respondente wat jonger as 19 jaar was, het die hoogste gemiddelde telling verkry $(\overline{\mathrm{X}}=87.83 ; 10.59)$. Diegene wat 60 jaar en ouer was, het die laagste gemiddelde telling gehad $(\overline{\mathrm{X}}=85.23 ; 10.31)$. Sien Tabel 5.

Die meerveranderlike variansie-ontleding wat uitgevoer is ten einde hierdie navorsingshipotese te toets, het getoon dat drie veranderlikes van subskaal B op die 1\%-peil statistiesbeduidend was, te wete die streek, die huwelikstatus en die geslag. Ten opsigte van subskaal $C$, wat gehandel het oor vroue in die amp met spesifieke verwysing na die prediking, was slegs die streek op die 1\%-peil beduidend. Wat subskaal $\mathrm{D}$ betref, was slegs die streek en die geslag op die 1\%-peil statisties-beduidend, terwyl die huwelikstatus op die 5\%-peil beduidend was. Vir die totale vraelys was die streek en die geslag weereens op die 1\%-peil statisties-beduidend, terwyl die huwelikstatus op die 5\%-peil beduidend gemeet het.

Cohen se d-toets is aangewend ten einde die praktiese belang van die veranderlikes te bepaal. Hierdeur is vasgestel of die verskille 'n verdere ondersoek noodsaak (Koen 2008:95). Die streek, die huwelikstatus en die geslag, soos gemeet deur subskaal B, beskik oor 'n groot praktiese beduidendheid, terwyl die ouderdom oor ' $n$ matige praktiese beduidendheid beskik. Slegs die streek toon 'n beduidende praktiese effek ingevolge subskaal $C$, terwyl die streek en die geslag 'n beduidende praktiese effek op subskaal D behaal het. Die huwelikstatus toon egter'n matige praktiese effek op subskaal D. Na aanleiding van die riglynwaardes blyk dit dus dat die streek, die geslag en die huwelikstatus beduidende praktiese effekgroottes vir die totale skaal toon.

Die resultate van die Scheffé-toets het aangedui dat die respondente van die Vrystaat beduidend hoër tellings as die respondente uit Gauteng op subskaal D sowel as op die totale
TABEL 1: Beskrywinde statistiese resultate vir die veranderlike stad en platteland

\begin{tabular}{|c|c|c|c|c|c|c|}
\hline \multirow{2}{*}{$\begin{array}{l}\text { Geografiese } \\
\text { ligging }\end{array}$} & \multirow[t]{2}{*}{$N$} & \multirow[t]{2}{*}{$X$} & \multicolumn{3}{|c|}{ Subskale } & \multirow{2}{*}{$\begin{array}{l}\text { Totale } \\
\text { skaal }\end{array}$} \\
\hline & & & Subskaal B & Subskaal C & Subskaal D & \\
\hline \multirow[t]{2}{*}{ Stad } & 437 & $\bar{x}$ & 29.76 & 27.04 & 29.63 & 86.44 \\
\hline & & $S$ & 4.30 & 3.74 & 5.00 & 10.23 \\
\hline \multirow[t]{2}{*}{ Platteland } & 575 & $\bar{x}$ & 29.44 & 26.95 & 29.42 & 85.81 \\
\hline & & $S$ & 4.41 & 4.32 & 5.11 & 11.20 \\
\hline \multirow[t]{2}{*}{ Totaal } & 1048 & $\bar{x}$ & 29.59 & 26.99 & 29.52 & 86.09 \\
\hline & & $S$ & 4.36 & 4.07 & 5.06 & 10.77 \\
\hline
\end{tabular}

TABEL 2: Beskrywende statistiese resultate vir streeksverspreiding as onafhanklike veranderlike.

\begin{tabular}{|c|c|c|c|c|c|c|}
\hline \multirow[t]{2}{*}{ Streek } & \multirow[t]{2}{*}{$N$} & \multirow[t]{2}{*}{$X$} & \multicolumn{3}{|c|}{ Subskale } & \multirow{2}{*}{$\begin{array}{l}\text { Totale } \\
\text { skaal }\end{array}$} \\
\hline & & & Subskaal B & Subskaal C & Subskaal D & \\
\hline \multirow[t]{2}{*}{ KwaZulu-Natal } & 134 & $\bar{x}$ & 30.10 & 27.52 & 30.19 & 87.81 \\
\hline & & $\mathrm{S}$ & 3.80 & 3.77 & 4.62 & 9.11 \\
\hline \multirow[t]{2}{*}{ Vrystaat } & 179 & $\bar{x}$ & 30.60 & 27.30 & 30.66 & 88.56 \\
\hline & & $\mathrm{S}$ & 4.10 & 3.76 & 4.39 & 9.38 \\
\hline \multirow[t]{2}{*}{ Noord-Wes } & 88 & $\bar{x}$ & 30.07 & 27.44 & 29.57 & 87.08 \\
\hline & & $\mathrm{S}$ & 4.35 & 3.60 & 5.43 & 10.87 \\
\hline \multirow[t]{2}{*}{ Gauteng } & 146 & $\bar{x}$ & 28.99 & 26.53 & 28.23 & 83.75 \\
\hline & & $\mathrm{S}$ & 4.56 & 3.65 & 5.73 & 11.39 \\
\hline \multirow[t]{2}{*}{ Oos-Kaаp } & 96 & $\bar{x}$ & 29.43 & 27.54 & 29.84 & 86.81 \\
\hline & & $\mathrm{S}$ & 4.77 & 5.18 & 5.22 & 12.48 \\
\hline \multirow[t]{2}{*}{ Wes-Kaap } & 90 & $\bar{x}$ & 29.07 & 26.81 & 27.73 & 83.61 \\
\hline & & $\mathrm{S}$ & 3.98 & 3.49 & 4.78 & 8.67 \\
\hline \multirow[t]{2}{*}{ Noord-Kaap } & 108 & $\bar{x}$ & 28.82 & 26.15 & 28.98 & 83.94 \\
\hline & & $\mathrm{S}$ & 4.66 & 4.76 & 4.89 & 11.23 \\
\hline \multirow[t]{2}{*}{ Limpopo } & 97 & $\bar{x}$ & 28.86 & 26.57 & 29.64 & 85.06 \\
\hline & & $\mathrm{S}$ & 4.21 & 3.73 & 4.87 & 10.89 \\
\hline \multirow[t]{2}{*}{ Mpumalanga } & 110 & $\bar{x}$ & 29.66 & 26.96 & 30.10 & 86.72 \\
\hline & & $\mathrm{S}$ & 4.61 & 4.51 & 5.10 & 12.02 \\
\hline \multirow[t]{2}{*}{ Totale groep } & 1048 & $\bar{x}$ & 29.59 & 26.99 & 29.52 & 86.09 \\
\hline & & $S$ & 4.36 & 4.07 & 5.06 & 10.77 \\
\hline
\end{tabular}

TABEL 3: Beskrywende statistiese resultate vir huwelikstatus as onafhanklike veranderlike.

\begin{tabular}{lcccccc}
\hline Huwelikstatus & $N$ & $X$ & \multicolumn{3}{c}{ Subskale } & $\begin{array}{l}\text { Totale } \\
\text { skaal }\end{array}$ \\
\cline { 3 - 6 } & & & Subskaal B & Subskaal C & Subskaal D & \\
\hline Getroud & 289 & $\bar{X}$ & 29.64 & 26.79 & 29.57 & 86.00 \\
& & $\mathrm{~S}$ & 4.44 & 4.42 & 5.78 & 11.67 \\
Ongetroud & \multirow{2}{*}{638} & $\bar{X}$ & 29.68 & 27.17 & 29.61 & 86.45 \\
& & $\mathrm{~S}$ & 4.39 & 4.03 & 4.84 & 10.69 \\
Geskei & \multirow{2}{*}{69} & $\bar{X}$ & 29.77 & 26.86 & 29.09 & 85.71 \\
& & $\mathrm{~S}$ & 4.12 & 3.67 & 4.32 & 9.55 \\
Weduwee of & \multirow{2}{*}{33} & $\overline{\mathrm{X}}$ & 28.28 & 26.51 & 28.57 & 83.36 \\
Wewenaar & & $\mathrm{S}$ & 3.95 & 3.20 & 4.65 & 8.93 \\
Totaal & \multirow{2}{*}{1049} & $\bar{X}$ & 29.60 & 27.01 & 29.51 & 86.12 \\
& & $\mathrm{~S}$ & 4.37 & 4.08 & 5.08 & 10.83 \\
\hline
\end{tabular}

TABEL 4: Beskrywende statistiese resultate vir geslag as onafhnaklike veranderlike.

\begin{tabular}{llccccc}
\hline Geslag & $\boldsymbol{N}$ & $\boldsymbol{X}$ & \multicolumn{3}{c}{ Subskale } & $\begin{array}{c}\text { Totale } \\
\text { skaal }\end{array}$ \\
\cline { 3 - 6 } & & & Subskaal B & Subskaal C & Subskaal D & \\
\hline Manlik & 413 & $\bar{X}$ & 28.38 & 26.81 & 28.30 & 83.49 \\
& & $\mathrm{~S}$ & 4.60 & 4.60 & 5.45 & 12.15 \\
Vroulik & 639 & $\bar{X}$ & 30.39 & 27.12 & 30.30 & 87.81 \\
& & $\mathrm{~S}$ & 4.02 & 3.70 & 4.66 & 9.50 \\
Totaal & \multirow{2}{*}{1052} & $\bar{X}$ & 29.60 & 27.00 & 29.52 & 86.11 \\
& & $\mathrm{~S}$ & 4.37 & 4.08 & 5.08 & 10.82 \\
\hline
\end{tabular}

vraelys gehad het. Die Vrystaatse respondente het ook hoër tellings as die respondente van die Wes-Kaap op subskaal D gehad. Ten spyte van die statisties-beduidende verskille vir die huwelikstatus, het geeneen van die onderskeie Scheffé- 
TABEL 5: Beskrywende statistiese resultate vir ouderdomsgroepe as onafhanklike veranderlike.

\begin{tabular}{llccccc}
\hline Ouderdom & $N$ & $X$ & \multicolumn{3}{c}{ Subskale } & $\begin{array}{l}\text { Totale } \\
\text { skaal }\end{array}$ \\
\cline { 3 - 6 } & & & Subskaal B & Subskaal C & Subskaal D \\
\hline Jonger as 19 & 276 & $\bar{X}$ & 30.15 & 27.53 & 30.16 & 87.83 \\
& & $S$ & 4.41 & 3.84 & 4.84 & 10.59 \\
20-39 & \multirow{2}{*}{390} & $\bar{X}$ & 29.16 & 26.83 & 29.35 & 85.34 \\
& & $S$ & 4.35 & 4.38 & 4.80 & 10.59 \\
$40-59$ & 258 & $\bar{X}$ & 29.60 & 26.83 & 29.44 & 85.87 \\
& & $S$ & 4.40 & 4.11 & 5.58 & 11.51 \\
$60+$ & 127 & $\bar{X}$ & 29.72 & 26.70 & 28.80 & 85.23 \\
& & $S$ & 4.19 & 3.51 & 5.27 & 10.31 \\
Totaal & 1051 & $\bar{X}$ & 29.60 & 27.00 & 29.52 & 86.11 \\
& & $S$ & 4.37 & 4.08 & 5.08 & 10.83 \\
\hline
\end{tabular}

toetsresultate beduidende verskille op enige van die subskale uitgewys nie. Aangesien die onafhanklike veranderlike, die geslag, slegs twee kategorieë bevat, is t-toetse op elkeen van die subskale uitgevoer om die verskille tussen die gemiddeldes vir die manlike en die vroulike respondente te toets. Hieruit het geblyk dat die mans se gemiddelde tellings op subskaal B, D en die totale vraelys beduidend laer was as dié van die vroue.

\section{Bespreking van resultate}

Die steekproef van 1052 kerklidmate verteenwoordig 'n toevallige steekproeftrekking, gebaseer op beskikbaarheid en dit voeldoen dus nie aan die vereistes vir eksterne geldigheid nie. Tog kan kennis geneem word van die resultate van die onderhawige studie, wat op ' $n$ interafhanklike invloed tussen die demografiese veranderlikes en die kerklidmate se houding teenoor vroulike ampsdraers dui. Die belangrikste kwantitatiewe bevindings van die studie was dat die kerklidmate deurgaans 'n positiewe houding aangaande vroulike ampsdraers huldig. Hierdie positiewe bevindings stem ooreen met dié van Piper en Grudem (2006:469). Hulle toon dat die verskillende denominasies ' $n$ positiewe houding teenoor vroulike leraars vermeld ten spyte van die voorkoms van onderliggende, hoewel subtiele, teenkanting.

Hierdie positiewe tendens is onder andere waargeneem in die Nederduitse Gereformeerde Kerk waar vroulike leraars wel beroep word. Die aantal vroulike leraars in permanente poste weeg egter nie op teen die hoeveelheid manlike leraars wat permanent aangestel word nie (Büchner 2007:24). Die tendens is volgens die bevindings ook in kerke teenwoordig waar 'n verbod op vroulike ampsdraers met spesifieke verwysing na die leer- en regeerampte steeds staan. Hieronder val die Gereformeerde Kerke van SuidAfrika (GKSA) (Meijer 2009:4-5) en die Rooms-Katolieke Kerk (Power 2008:325).

Die resultate van die meerveranderlike variansie-ontleding het getoon dat die geslag en die streek, demografiese veranderlikes is wat die kerklidmate se houding teenoor vroulike ampsdraers statisties hoogs-beduidend beïnvloed soos deur die totale vraelys gemeet is. Hierdie twee genoemde veranderlikes sowel as die huwelikstatus beskik volgens Cohen se $d$-toets, oor groot praktiese beduidendheid, hoewel laasgenoemde (die huwelikstatus) geen beduidende verskille op enige van die subskale getoon het nie. Hieruit kan dus afgelei word dat 'n persoon se geslag, uit watter streek die persoon ook al kom, sowel as die huwelikstatus 'n groot invloed op die houding jeens die vroulike amspdraers sal hê.

Ten opsigte van die geslag toon die studie dat die manlike respondente statisties-beduidend laer gemiddelde tellings verkry het as die vroulike respondente op subskaal B (wat handel oor vroue in die algemeen), asook op subskaal D (wat die respons wat die houding ontlok, meet). Mans se houdings teenoor vroue in die algemeen, asook vroulike ampsdraers is hiervolgens beduidend minder positief as dié van vroue. Hierdie bevindings strook gevolglik nie met dié van Rees (2003:113-116) nie (vgl. 'Geslag'). Die rede hoekom mans minder positief ingesteld is, kan moontlik gesoek word in die sterk klem wat tans op vroueregte en gepaardgaande regstellende aksie (soms ten koste van mans) geplaas word.

Voorts toon die resultate dat kerklidmate in die Vrystaat statisties-beduidend verskil van die lidmate van Gauteng en die Wes-Kaap op subskaal C (wat spesifiek oor vroulike ampsdraers gehandel het). Hiervolgens huldig lidmate van die Vrystaat 'n positiewer houding teenoor vroulike deelname in die amp. Die Vrystaatse lidmate se positiewe houding word ook deur hulle gesindheid getoon dat vroulike leraars die geleentheid gebied moet word om hulself te bewys. Hierdie empiriese resultate is teenstrydig met die verwagtings, aangesien daar algemeen aanvaar word dat die Vrystaat oor 'n sterk behoudende en konserwatiewe element beskik. Tog is dit ook waar dat die eerste vrou wat beroep is, in Bloemfontein beroep is.

Volgens Cohen se $d$-toets beskik die huwelikstatus oor groot praktiese beduidendheid en is beduidend op die 1\%peil, hoewel die post hoc-toetsresultate geen verskille kon identifiseer nie. Die huwelikstatus van respondente beïnvloed dus wel die respondent se houding teenoor vroulike ampsdraers, maar dit behoort verder ondersoek te word. Geen verskille is ten opsigte van die ouderdom en tussen die stads- en plattelandse gemeentes gevind nie. Gebaseer op die kwantitatiewe resultate van die studie, kan die navorsingshipotese dus slegs gedeeltelik aanvaar word.

\section{Gevolgtrekking}

Die houding teenoor vroulike ampsdraers in die kerk word nie bloot deur teologiese argumente beïnvloed nie. Dit word ook deur bepaalde demografiese veranderlikes beïnvloed soos in hierdie studie aangetoon is. Die kerklidmate in hierdie studie was deurgaans positief jeens vroulike ampsdaers in die kerk. Ongetroudes, vroue en respondente uit die Vrystaat het die mees positiewe houding in hierdie verband getoon.

Die resultate en bevindings van hierdie studie is wel betekenisvol. Vanuit 'n sosiaal-psigologiese paradigma dra die studie by tot die verdieping van bestaande wetenskaplike 
kennis in die navorsing van houdings. 'n Wesenlike bydrae tot die uitbreiding van die onderwerp, is ook gelewer. Die teoretiese grondslag op grond waarvan houdings ondersoek word, is belig en op die Suid-Afrikaanse bevolking getoets deur die ontwikkeling van 'n toepaslike meetinstrument. Die kognitiewe-affektiewe-konatiewe model waarop hierdie studie, asook ' $n$ deel van die meetinstument gebaseer is, is verder ontwikkel en uitgebrei. Die bevindings dra ook by tot die kennis van kerke oor hulle lidmate se houding jeens vroulike ampsdraers in die kerk.

\section{Tekortkomings en aanbevelings}

Op grond van hierdie kwantitatiewe navorsing kan die volgende tekortkomings gestel word en gepaardgaande aanbevelings gemaak word:

- Aangesien daar nie 'n vraelys was om kerklidmate se houding teenoor vroulike ampsdraers te meet nie, moes die navorser ' $n$ vraelys saamstel. Die aspek rakende die vraelys behoort deur toekomstige navorsing uitgebrei te word. Op hierdie wyse kan konvergente en divergente geldigheid verhoog word.

- Aangesien die onderhawige studie beskrywend van aard was, kan daar in die toekoms ondersoek ingestel word na die moontlike interaksie tussen die veranderlikes.

\section{Erkenning}

Hierdie artikel is deel van Petronella Jonck se doktorale proefskrif wat toegestaan is by die Universiteit van die Vrystaat in 2011 deur die Departement Sielkunde.

\section{Mededingende belange}

Die outeur(s) verklaar dat sy geen finansiële of persoonlike verbintenis het met enige party wat haar nadelig kon beïnvloed het in die skryf van hierdie artikel nie.

\section{Literatuurverwysings}

Büchner, E.P., 2007, “"Ek het 'n roeping”: Vrouepredikante se toelating in die Nederduitse Gereformeerde Kerk: 'n Kerkhistoriese en prakties-teologiese studie', Ongepubliseerde proefskrif, Departement van Teologie, Universiteit van Pretoria Pretoria.

Cheung, R.M., Noel, S. \& Hardin, C.D., 2011, 'Adopting the system attitudes of others: Effects of trivial interpersonal connections in the context of social inclusion Effects of trivi, in in (a) effek van en uitsluiting], Social Cognition 29(3), 255-269. http://dx.doi.org/10.1521/ en uitsluiting], Social

Cohick, L.L., 2006, 'Prophecy, women in leadership and the body of Christ', in M. Husbands \& T. Larsen (eds). Women, ministry and the gospel:Exploring new paradigms, pp. 81-97, InterVarsity, Downers Grove.

De Beer, E.J., 2007, "n Teologies-etiese beoordeling van regstellende aksie', In die Skriflig 41(1), 109-133. http://dx.doi.org/10.4102/ids.v41i1.298

De Houwer, J., 2011, 'The dominance of associative theorizing in implicit attitude research: Propositional and behavioral alternatives' [Die dominansie van assosiatiewe teoretiseing in implisiete verhoudingsnavorsing: Voorstellende en gedragsalternatiewe], The Psychological Record 61:465-496.

Deddens, K., 1988, 'Het ambt en de vrouw', in P.J. Rossouw (red.), Gereformeerde ampsbediening, bl. 340-356, NG Kerkboekhandel, Pretoria.

Dreyer, Y., 2006, 'Vroue in die sinoptiese Evangelies - Méér as dekoratiewe karakters', HTS 58(4), 1679-1705.

Du Plooy, G. \& Grobler, J., 2002, 'Afrikaans as televisietaal in Suid-Afrika: 'n Toekomsperspektief', Communication 28(2), 8-17.

Du Plooy-Clilliers, F. \& Louw, M, 2003, Let's talk about interpersonal communication, Heinemann, Sandton.
Ebere, C., 2011, 'Beating the masculinity game: Evidence from African traditional religion' [Klop die manlikheidspel: Getuienis van die tradisionele Afrikagodsdiens], Cross Currents: Association for Religion and Intellectual Life, 480-495.

Gore, T. \& Hollywood, E., 2009, 'The role of social networks and geographical location in labour market participation in the UK coalfields' [Die rol van sosiale netwerke en geografiese ligging in arbeidsmarkdeelname in die VK se steenkoolvelde] Environment and Planning C: Government and Policy 27(6), 1008-1021. http:// dx.doi.org/10.1068/c0850

Hamman, J.J., 2010, 'Resistance to women in ministry and the psychodynamics of sadness' [Die teenstand teen vroue in die bediening en die psigodinamiek van hartseer], Pastoral Psychology 59, 769-781. http://dx.doi.org/10.1007/s11089010-0299-2

Hendriks, J., 2003, Die toekoms van die kerk, die kerk van die toekoms, Universiteit van Stellenbosch, Stellenbosch,

Hurley, J.B., 1981, Man and woman in biblical perspective, Zondervan, Grand Rapids.

Jasinskaja-Lahti, I., Liebkind, K. \& Solheim, E., 2009, 'To identify or not to identify? National disidentification as an alyetnative reaction to perceived ethnic discrimination' $[\mathrm{Om}$ te identifiseer of om nie te identifiseer nie? Nasionale disidentifikasie as ' $n$ 'alyet'-inwonerreaksie ten opsigte van waargenome etniese diskrimitasie], Applied psychology: An international review 58(1), 105-128. http:// dx.doi.org/10.1111/j.1464-0597.2008.00384.x

Jonck, P., Le Roux, A. \& Verster, P., 2007, "n Sosiaal-psigologiese perspektief op lidmate in die Manguang-area se houding teenoor kerkvereniging in die Nederduitse Gereformeerde Kerkfamilie: 'n Kruiskulturele ondersoek', In die Skriflig 41(1) 45-68. http://dx.doi.org/10.4102/ids.v41i1.295

Kleynhans, R. \& Kotzé, M., 2010, 'Bestuurders en werknemers se houding teenoor persone met fisieke gestremdhede in die werkplek', Tydskrif vir Geesteswetenskappe 50(3), 404-417.

Kloppers, M.H.O., 1988, 'Die ontwikkeling van die amp in die Ou Testament', in P.J. Rossouw (red.), Gereformeerde ampsbediening, bl. 7-23, NG Kerk Boekhandel, Pretoria.

Koen, A., 2008, 'Die verband tussen emosionele intelligensie en psigologiese welstand van adolessente: 'n Multikulturele ondersoek', Ongepubliseerde proefskrif, Departement van Sielkunde, Universiteit van die Vrystaat, Bloemfontein.

Leavitt-Alcántara, B., 1999, 'Practicing faith: Laywomen and religion in Central America 1750-1870', Ongepubliseerde doktorale proefskrif, Departement van Geskiedenis, Universiteit van California, Berkely.

Leedy, P.D. \& Ormrod, J.E., 2010, Practical research: Planning and design, 9th ed., Pearson Education, New Jersey.

Lummis, A.T. \& Nesbitt, P.D., 2000, Women clergy research and the sociology of religion. Sociology of Religion, viewed 10 June 2009, from http://findarticles. $\mathrm{com} / \mathrm{p} / \mathrm{articles} / \mathrm{minOSOR} / \mathrm{is} 461 / \mathrm{ai} 69494367$

Meijer, G.J., 2009, 'GKSA Sinode 2009', Waarheid en Dwaling 15, 4-5.

Obst, P., White, K.M., Mavor, K.I. \& Baker, R.M., 2011, 'Social identification dimensions as mediators of the effect of prototypicality on intergroup behaviours' [Sosiale identifikasiedimensies as tussengangers in die uitwerking van protokenmerke op intergroepsgedrag], Psychology 2(5), 426-432. http://dx.doi.org/10.4236/ psych.2011.25066

Piper, J. \& Grudem, W. (eds.), 2006, Recovering biblical manhood and womenhood: A response to evangelical feminism, Wheaton, Crossway.

Potgieter, A.V., 1994, 'Rolvoorskrifte vir die predikant in die oorgangsfase na 'n geïntegreerde gemeenskap en gemeente', Ongepubliseerde magisterverhandeling, Fakulteit Teologie, Universiteit van die Vrystaat, Bloemfontein.

Power, D.N., 2008, Mission, ministry, leadership, order: Reading the tradition in the present context, Continuum, New York.

Prinsloo, W.S., 1988, 'Die funksionering van die "amp" in die Ou Testament', in P.J. Rossouw (red.), Gereformeerde ampsbediening, bl. 2-39, NG Kerk Boekhandel, Pretoria.

Rees, S., 2003, 'An examination of the biblical role of women in conteporary church life', Unpublished thesis, Department of Theology, University of Zululand, Richards Bay

Salkind, N.J., 2012, Exploring research, 8th ed., Pearson Education, New Jersey.

Smit, J., 2012, 'Watter pad kan ons volg met die vrou in die amp ná Sinode 2012?' Die Kerkblad, 9, Februarie.

Sparrow, I., 2006, 'An exploratory study of women's experiences and place in the church: A case study of a parish in the church of the province of South Africa (CPSA), Diocese of Cape Town, Unpublished thesis, Faculty of Arts, University of Western Cape, Bellville.

Stewart-Thomas, M., 2010, 'Gendered congregations, gendered service: The impact of clergy gender on congregational social service participation' [Geslagtelikheid in gemeentes en dienste: Die impak van klerikale geslagtelikheid op gemeentelike sosiale diensdeelname]' Gender, Work and Organizations 17(4), 406-432.

Taylor, S.F., Peplau, L.A. \& Sears, D.O., 2003, Social psychology, 11th ed., Prentice Hall, New Jersey.

Tervo, R.C., Palmer, G. \& Redinius, P., 2004, 'Health professional student attitudes towards people with disabilities' [Professionele Gesondheidsorgstudente se houdings teenoor mense met gestremdhede], Clinical Rehabilitation 18, 908-915. http://dx.doi.org/10.1191/0269215504cr820oa, PMid:15609846

Todd, A.R., Galinsky, A.D. \& Bodenhausen, G.V., 2012, 'Perspective taking undermines stereotype maintenance processes: Evidence from social memory, behaviour explanation, and information solicitation' [Om perspektief te verkry, ondermyn die onderhoudingsprosesse van stereotipering: Getuienisse van sosiale geheue die onderhoudingsprosesse van stereotipering: Getuienisse van sosiale geheue,
gedragsverklaring en inligtingsversoeke], Social Cognition 30(1), 94-108. http:// gedragsverklaring en inligtingsversoek
dx.doi.org/10.1521/soco.2012.30.1.94

Van Helden, P., 2002, 'Die aktiwiteite van die belydende GKSA-vrouelidmaat tydens die erediens', In die Skriflig 36(4), 753-784. http://dx.doi.org/10.4102/ids.v36i4.533 